\title{
1 Colocation opportunities for large solar infrastructures and agriculture in drylands
}

2 Sujith $\operatorname{Ravi}^{a \dot{\dagger}}$, Jordan Macknick $^{b}$, David Lobell ${ }^{c}$, Christopher Field ${ }^{d c}$, Karthik Ganesan ${ }^{\mathrm{e}}$, Rishabh

3 Jain $^{\text {fe }}$, Michael Elchinger ${ }^{b}$, Blaise Stoltenberg ${ }^{b}$

4

$5 \quad{ }^{a}$ Department of Earth \& Environmental Sciences, Temple University, 1901 N. $13^{\text {th }}$ Street,

$6 \quad$ Philadelphia, PA 19122, USA. Tel: 001703581 8186; E-mail: sravi@temple.edu

$7 \quad{ }^{b}$ National Renewable Energy Laboratory (NREL), 15013 Denver West Parkway, Golden, CO

880401.

9

10

11

12

13

14

15

16

$17{ }^{\dagger}$ Corresponding author

18

19

20

21 22

23

24

25

26 Keywords: Renewable energy, Life Cycle Assessment, Water use efficiency, Land use, Food-

27

${ }^{c}$ Department of Environmental Earth System Science, Stanford University, 473 Via Ortega, Stanford, CA 94305, USA.

${ }^{d}$ Department of Global Ecology, Carnegie Institution for Science, Stanford, CA 94301, USA

${ }^{e}$ Council on Energy, Environment \& Water, New Delhi 110001, India.

${ }^{f}$ Lee Kuan Yew School of Public Policy, National University of Singapore, Singapore 119077, Singapore. 8 19 20 1

3
7 Energy-Water Nexus 


\section{Abstract}

29 Solar energy installations in arid and semi-arid regions are rapidly increasing due to technological advances and policy support. Although solar energy provides several benefits such

31 as reduction of greenhouse gases, reclamation of degraded land, and improved quality of life in

32 developing countries, the deployment of large-scale renewable energy infrastructure may

33 negatively impact land and water resources. Meeting the ever-expanding energy demand with

34 limited land and water resources in the context of increasing demand for alternative uses such as

35 agricultural and domestic consumption is a major challenge. The goal of this study was to explore opportunities to colocate solar infrastructures and agricultural crops to maximize the

37 efficiency of land and water use. We investigated the energy inputs/outputs, water use,

38 greenhouse gas emissions, and economics of solar installations in northwestern India in comparison to aloe vera cultivation, another widely promoted and economically important land use in these systems. The life cycle analyses show that the colocated systems are economically viable in some rural areas and may provide opportunities for rural electrification and stimulate

42 economic growth. The water inputs for cleaning solar panels are similar to amounts required for 43 annual aloe productivity, suggesting the possibility of integrating the two systems to maximize 44 land and water use efficiency. A life cycle analysis of a hypothetical colocation indicated higher 45 returns per $\mathrm{m}^{3}$ of water used than either system alone. The northwestern region of India has 46 experienced high population growth in the past decade, creating additional demand for land and 47 water resources. In these water-limited areas, coupled solar infrastructure and agriculture could 48 be established in marginal lands with low water use, thus minimizing the socioeconomic and environmental issues resulting from cultivation of economically important non-food crops (e.g., 50 aloe) in prime agricultural lands. 
52 Population growth and increase in standards of living in the developing world have led to a rapid

53 increase in energy demand [1]. At the same time, in the context of climate change mitigation,

54 many governments worldwide have policies to increase the proportion of electricity delivered by

55 low-carbon sources [2-4]. Solar electricity generation technologies have emerged as one of the

56 fastest growing sectors due to rapid advances in affordable technology and policy support [2].

57 Solar energy deployment can provide several additional benefits such as reclamation of degraded

58 land, employment opportunities, rural electricity access (off-grid systems), and improved quality

59 of life in developing countries [5-7]. However, the deployment of large scale solar energy

60 infrastructure may negatively impact land and water resources [8,9]. Hence a pertinent question

61 for the future is how to meet the ever-expanding energy demand in the developing world with

62 limited land and water resources in the context of increasing demand for alternative uses such as

63 agricultural and domestic consumption [10,11].

64

65 The rapid expansion of large-scale solar installations in India is a case in point. Energy demand

66 is rapidly increasing in India and the country has experienced severe power outages resulting

67 from the interplay of several factors, including increasing demand, energy use for irrigation, and

68 uncertainties in water availability induced by climate change [1,12]. In northwestern India, large

69 solar installations are being established as part of the national and state renewable energy

70 initiatives to meet the future energy targets $[13,14]$. In many of the "hotspots" identified for large

71 solar installations, water resources are already scarce, such as in the Thar desert region of

72 northwestern India $[15,16]$. The northwestern region of India (e.g., state of Rajasthan) has shown

73 rapid increase in population over the last few decades creating additional demand for agricultural 
74 land and water resources [17-19]. Most of the proposed solar installations will be large

75 photovoltaic (PV) systems, which can have a large land footprint $\left(0.35 \mathrm{MW} \mathrm{ha}^{-1}\right)[8,9,13]$.

76 Although their water use per unit of generation is less than many other energy technologies $(0.02$

$77 \mathrm{~m}^{3} \mathrm{MWh}^{-1}$ ), due to their size they can use substantial amounts of water for construction and

78 operation, mostly for cleaning PV solar panels and for dust suppression from disturbed soils

$79[8,9,20]$.

80

81 The accumulation of airborne particulate matter or "soiling" can significantly impact the

82 performance of PV systems in areas where rainfall is limited [21-23]. The construction and

83 operation of large PV facilities in deserts may add additional disturbance to desert soils and

84 enhance dust emissions. Further, increases in dust production related to climate change (e.g.,

85 increase in aridity), or disturbance (e.g., fires, grazing) to biological soil crusts [24,25] may

86 render the dust management in large solar facilities in arid regions challenging. Considering the

87 deleterious impact of dust-borne contaminants on regional air quality and human health,

88 enhanced dust emissions related to the construction and operation of large solar installations may

89 be a serious health hazard to consider [24,25]. For this reason, proper dust control strategies are

90 necessary at large solar infrastructures in deserts to ensure efficient power generation and to

91 minimize environmental impacts. In most PV facilities in arid regions, solar panels are routinely

92 washed with water to maintain optimum power production $[21,22,26]$. The soiling of panels may

93 result in 15-25\% decline in annual electricity production and weekly cleaning of panels is

94 recommended in many desert regions $[23,26]$. Studies have shown that water for washing panels

95 and for dust suppression is a major component of water budget of many large solar

96 infrastructures in desert regions [8]. In some areas with severe water scarcity, including areas in 
97 northwestern India, even the relatively small water requirements for solar PV installations

98 (compared with other energy technologies) may place a major demand on local water resources

99 or may displace water allocated for small-scale subsistence agriculture and domestic

100 consumption. Most of the applied water runs off the panels and into the desert soil, and this

101 moisture input may be sufficient to maintain some vegetation cover [8].

102

103 An emerging option being evaluated in the United States is the colocation of solar installations

104 and vegetation [8,27] (Figure 1a). Colocating solar infrastructure and agriculture (including

105 bioenergy) crops would provide additional benefits such as dual income streams to farmers,

106 employment opportunities at solar facilities for crop management, options for rural

107 electrification, and electricity for processing agriculture products locally [8]. A major constraint

108 for establishing colocated systems is identifying location-specific, physiologically and

109 economically viable plants for colocation. Most solar installations are sited in arid and semi-arid

110 regions characterized by low precipitation and poor soils, making them unsuitable for most food

111 crops. However, there is increasing interest in growing high-value xerophytic plants (e.g., Agave

112 spp., Aloe spp., Opuntia spp.) in marginal lands in arid and semi-arid regions that can be

113 cultivated without competition for key resources for food crops [8,28,29].

115 Aloe vera, a perennial leaf succulent xerophytic plant with ecological and physiological

116 adaptations to achieve economical yields on marginal lands [30,31], has potential for colocation

117 with solar infrastructure. The genus Aloe, which includes more than 300 species, has been used

118 for economical and medicinal purposes for centuries [31,32,33]. Aloe vera leaf contains a diverse

119 array of compounds; over 200 active compounds (including minerals, amino acids and vitamins) 
120 and are utilized in several formulations and applications in diverse sectors [31,32,34]. Aloe vera

121 cultivation offers numerous product diversification opportunities suitable for different climatic

122 conditions and markets (e.g., aloe gel, aloe vera seeds, roots, aloin, cosmetics, health drinks,

123 medicinal formulations, and biodiesel). The aloe gel, a colorless mucilaginous gel obtained from

124 the parenchymatous cells in the leaf, is in high demand in the food and pharmaceutical industry,

125 primarily as a major constituent in health drinks, natural medicines, and cosmetics [35]. The leaf

126 gel is mostly composed of complex carbohydrates known for its medicinal values including

127 effects on wound healing, anti-inflammation, and immune modulation [35]. Aloin, an

128 anthraquinone contained in the leaf exudate, has several medicinal properties including blood

129 purification, laxation, and diuresis [31, 33].

130

131 Aloes are under commercial cultivation over large areas in India (Figure 1b), including the

132 northwestern arid and semi-arid regions [36,37]. Several characteristics of aloes make them an

133 attractive crop for colocation with solar infrastructure: short growth stature (0.3 to $0.6 \mathrm{~m})$,

134 significant biomass production with little or no irrigation, low maintenance, long crop cycle (5

135 years), availability of processing facilities and existing marketing chains, and high demand (and

136 value) for aloe gel and gel-based products. Aloes are drought-resistant species with Crassulacean

137 Acid Metabolism (CAM) photosynthetic pathway, which enable high plant water use efficiencies

138 under desert conditions [28,38]. The plants establish very well in relatively poor soils and are

139 known to grow well in partial shade (e.g., from solar panels) with no significant change in leaf

140 productivity and gel quality [39-41]. Aloes have a thick shallow root system, which enables them

141 to make use of light precipitation or irrigation (e.g., from water used for cleaning solar panels)

$142[31,33]$. 
143 Colocated solar and aloe vera (for gel production) installations could maximize the efficiency of 144 water use in drylands by coupling water use for cleaning panels and irrigation, minimizing dust 145 generation by increasing soil moisture and vegetation cover, minimizing impacts on natural areas 146 by deploying crop cultivation in existing large solar infrastructures, and stimulating economic 147 returns to improve livelihoods in rural areas. However, to explore the logistics and economic 148 feasibility of integrated solar PV-aloe vera systems, detailed life cycle analyses are needed. 149 Here, we conduct a detailed life cycle analysis for solar PV, aloe vera gel production, and a 150 hypothetical colocated solar-aloe system to explore the tradeoffs and synergies (in the context of 151 energy, water, and greenhouse gas emissions) between these two emerging land uses in 152 northwestern India. We also examine the economics of these systems and the potential for 153 improving rural livelihoods (employment generation, rural electrification). 


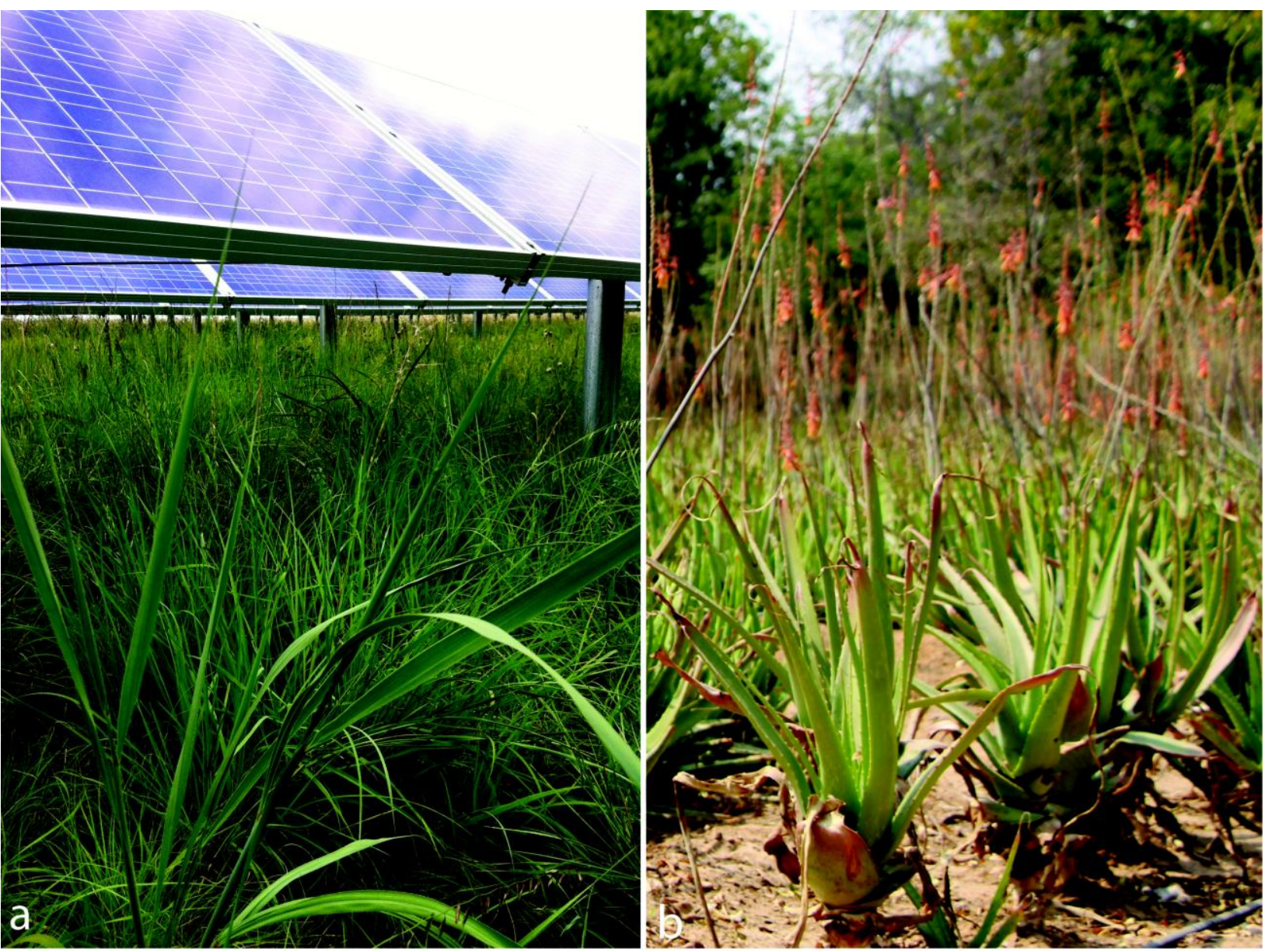

158 Figure 1 a) Colocation of Solar PV and vegetation in Colorado, USA. b) Aloe vera cultivation in 159 Rajasthan, India

\section{Material and Methods}

Life Cycle Analysis (LCA) is a commonly used tool for exploring the economic feasibility and environmental impacts of new technologies. Our analysis is based on a detailed life cycle analysis for a solar photovoltaic system, an Aloe vera gel production system, and a hypothetical colocated solar-aloe system to explore the tradeoffs and synergies between these two emerging land uses in northwestern India. In this study we adopted LCA methodologies used in existing 
167

168

comprehensive studies on solar PV and agricultural/biofuel production systems [8,42]. For Aloe vera, we used LCA methodologies to estimate the energy consumption, greenhouse gas emissions (GHG) and economic feasibility using different life cycle stages from cultivation to processing. For the LCA of solar PV installation, we used a compete analysis to estimate the energy consumption, greenhouse gas emissions (GHG) and offsets, economic feasibility. Our analysis includes all life cycle stages of solar PV - manufacturing PV modules and balance of system components (BOS), construction and operation, decommissioning, and recycling. Detailed description of LCA methodologies, input parameters and data sources are provided in the Supporting Information S1.

\subsection{Life cycle analysis of aloe vera gel}

The data required for life cycle analysis of aloe vera cultivation and gel processing are compiled from existing literature and from data collected during field visits to aloe vera farms and gel processing facilities in northwestern India. The life cycle stages for aloe vera gel production considered in this work are aloe cultivation, leaf harvest and transport, and gel production. In this scenario, the aloe vera leaves are harvested periodically and processed as gel. We take into account the life cycle fossil energy use and greenhouse gas emissions for direct energy and material inputs, machinery and buildings. We account for $\mathrm{CO}_{2}, \mathrm{CH}_{4}$, and $\mathrm{N}_{2} \mathrm{O}$ as GHG emissions with all emissions converted to $\mathrm{CO}_{2}$ equivalents based on their 100-year global warming potential $[8,42,53,54]$.

We consider two commercial scale cultivation scenarios of five-year cycle—baseline yield scenario and high yield scenario — with moderate levels of fertilizer/manure applications and 
189 irrigation. Aloe vera grows well in loamy to sandy loam soils and is sensitive to waterlogged 190 conditions. The plants flourish well in a semi-arid environment with $300 \mathrm{~mm}$ of annual rainfall 191 typical of northwestern India and are under commercial cultivation. The plants are established by 192 planting root suckers. The number of plants $\mathrm{ha}^{-1}$ ranges from 15,000 to 55,000 . The 193 commercially important species in India is Aloe barbedensis Miller (AL-1 variety). We adopt a 194 conservative planting density of 22,500 plants $^{-1} \mathrm{a}^{-1}$ based on the established cultivation practices 195 and data available from commercial aloe vera farms in northwestern India [43,44] (see 196 Supporting Information S1).

197 The application of fertilizers and manures varies with soil type, crop management, and climatic 198 factors. We chose values based on the general fertilizer recommendation for commercial aloe 199 cultivation in India [43-44]. In this study we use 50:50:50 $\mathrm{Kg} \mathrm{ha}^{-1}$ for nitrogen, phosphorus, and 200 potassium fertilizers (basal dose) as nutrients, respectively. For the high yield scenario, a top 201 dressing of an extra $25 \mathrm{Kg} \mathrm{ha}^{-1}$ of nitrogen is provided from the 2 nd year onward. The plant 202 responds very well to application of farmyard manure, and is applied at the rate of $15 \mathrm{Mg} \mathrm{ha}^{-}$ $203{ }^{1}$ year $^{-1}$. In northwestern India, a botanical pesticide and slow release $\mathrm{N}$ fertilizer known locally as 204 neem cake is added to control termites and to improve soil quality. Termites indeed can be an 205 issue in some areas during the early stages of crop establishment [36-37]. The use of plant 206 protection chemicals are not usually recommended as aloe products is commonly used in 207 cosmetics and health foods. However, in the case of leaf spot disease occurrence, fungicide 208 application is recommended in some areas.

209 The level of mechanization is very low in northwestern India [45], as the farm holdings are 210 relatively small. In this study we considered some level of mechanization for large commercial 211 aloe cultivations. Energy for farm operations - ploughing (twice before planting), 
212 fertilizer/manure application, and transportation — is assumed to come from diesel [45-46]. The

213 embedded energy for production and use of agricultural implements and farm machinery is

214 considered in the life cycle analysis. Planting, weeding, and harvesting are assumed to be done

215 manually. In the case of high yield scenario, the leaf residue from the gel processing plant is

216 applied to the soil as mulch/manure (see Supporting Information S1).

217 Aloe vera can be cultivated both under rain-fed and irrigated conditions. The plants can generate

218 economic yields with an annual rainfall of around $300 \mathrm{~mm}$ to $500 \mathrm{~mm}$, and can tolerate some

219 degree of drought $[32,36,37]$. Light irrigations immediately after planting and during summer

220 months will ensure better leaf production and gel quality. In the baseline yield scenario, plants

221 are irrigated twice immediately after planting and 6 additional times during the summer season

222 corresponding to once per month for six months. For the high yield scenario, plants are irrigated

223 twice immediately after planting and 24 additional times during the summer months

224 corresponding to once per week for six months. Several studies have indicated that the high leaf

225 biomass and gel quality are obtained by light irrigation in short weekly intervals [33,47].

226 Irrigation water requirements were collected from aloe vera farmers in northwestern India. Water

227 is manually applied at the rate of around $20 \mathrm{~m}^{3}$ per week (water volume per irrigation event) ha ${ }^{-1}$

$228(22,500$ plants). Irrigation water is normally groundwater and the power source is electricity (see

229 supporting information S1).

230 The harvesting starts 15 months after planting and there are at least three harvests per year. From

231 years two through five, two to four mature leaves from each plant are removed at harvest.

232 Economical harvest can be done up to the fifth year of planting. Harvesting is a manual labor-

233 intensive process. Average yield from commercial aloe cultivations is around $50 \mathrm{Mg} \mathrm{ha}^{-1} \mathrm{year}^{-1}$

234 fresh leaf weight $[43,48,49]$. Higher yields in the range of 75 to $100 \mathrm{Mg} \mathrm{ha}^{-1}$ year $^{-1}$ are reported $^{-1}$ 
235 in the literature. In this study we assumed a high yield scenario (fresh leaf weight) of $55 \mathrm{Mg} \mathrm{ha}^{-1}$

236 year ${ }^{-1}$ and a baseline yield scenario of $27 \mathrm{Mg} \mathrm{ha}^{-1}$ year $^{-1}$ (see Supporting Information S1).

237 Leaves show loss of biological activity a few hours after harvest, so leaves are processed within

23812 hours of harvesting. The processing stages for gel manufacturing are: leaf cleaning, leaf

239 filleting, gel extraction, filtration, homogenization, addition of preservatives, pasteurization,

240 cooling, and bottling/storage of gel/gel juice [35,50]. The manual leaf filleting process involves

241 cutting open the leaf from the sides and separating the gel from the outer part of the leaf (leaf

242 rind). Even though automated whole-leaf processing methods are available, the manual leaf

243 filleting process ensures better separation of pulp and minimizes the presence of undesirable

244 phenolic compounds from the leaf rind in the final gel product. The gel juice output is around

$24530 \%$ of the fresh leaf weight. In this life cycle analysis, we accounted for the embedded energy

246 and GHG emissions from transportation of leaves from farm to the processing facility (diesel

247 energy), processing machinery (e.g., washing unit, pulping unit, extractor, homogenizer, and

248 mixers), buildings, chemicals and lubricants, and the electricity for gel processing (see

249 Supporting Information S1).

$250 \quad 2.2$ Solar PV life cycle analysis

251 We considered a solar PV installation, as PV is the dominant technology for current and

252 proposed solar installations. Moreover, there might be other logistic constraints for colocation of

253 crops in concentrated solar power installations (CSP) due to intensive infrastructure. The

254 considered solar PV installation is installed in a desert environment, typical of northwestern

255 India, with an annual precipitation of $300 \mathrm{~mm}$ and a solar insolation of 2,000 $\mathrm{kWh} \mathrm{m}^{-2} \mathrm{year}^{-1}$

$256[16,51]$. This installation consists of a basic array of fixed flat plate systems with approximately 
2573250 multi-crystalline silicon (m-Si) PV modules of 120 Watt-peak (Wp), a module area of $1 \mathrm{~m}^{2}$,

258 and an efficiency of $15 \%$ [52]. The annual power generation is calculated via the HOMER

$259 \mathrm{model}^{\mathrm{a}}$ utilizing a solar resource of $5.80 \mathrm{kWh} \mathrm{m}^{-2} \mathrm{day}^{-1}$ for Northwestern India. Additional details

260 are available in the Supporting Information S2. The materials input and energy input, and

261 greenhouse gas emissions and outputs during the life cycles of $\mathrm{m}-\mathrm{Si}$ are considered from PV

262 production plants. The life cycle stages considered are manufacturing PV modules and balance

263 of system components, construction and operation, decommissioning, and recycling [53]

264 assuming a life cycle of 30 years. Large-scale solar installations in deserts require balance of

265 system components like module frames, mounting structures, grid connectors, concrete, and

266 office facilities. The energy inputs for manufacturing one MWp of m-Si module and balance of

267 system components total 31,333 GJ [52,54]. The GHG emissions for manufacturing the module

268 and balance of system components are 37 and $20 \mathrm{gCO}_{2} \mathrm{e} \mathrm{kWh}^{-1}$, respectively, over an expected

26930 years of useful life of a module [53,54]. We also consider the energy used for operation of the

270 PV infrastructure, mainly for the routine cleaning of panels. In this study we do not consider

271 additional pollutant emissions. Electricity generation by solar PV results in substantial GHG

272 offsets - reduction in GHG emissions resulting from electricity generation by renewable

273 technologies compared to conventional fossil-based electricity generation. We used the GHG

274 emissions from electricity generation in India for calculating the offsets resulting from solar PV-

275 based electricity generation. The life cycle fossil fuel energy use and GHG emissions to produce

276 this electricity is based on the Indian electricity generation mix of $3.4 \mathrm{MJ}$ and $278 \mathrm{gCO}_{2} \mathrm{e} \mathrm{MJ}^{-1}$

277 [55] of electricity produced respectively (See Supporting Information S2).

\footnotetext{
${ }^{a}$ HOMER (Hybrid Optimization of Multiple Energy Resources) software models micropower systems with single or multiple power sources. HOMER finds the least cost combination of components that meet electrical and thermal loads by simulating thousands of system configurations, optimizing for lifecycle cost, and generating results of sensitivity analyses on most inputs.
} 
278 The cleaning frequency assumed is once every week during the rainless periods (8 months) and

279 once every month for the rest of the year (total of 36 cleaning events per year). This cleaning

280 schedule is ideal for arid regions to minimize reductions in electricity output resulting from dust

281 deposition $[8,21,22]$. The water use per washing event is $20 \mathrm{~m}^{3} \mathrm{ha}^{-1}$ per wash for cleaning

282 panels and water for dust suppression from soil. Water requirements for panel washing and dust

283 suppression are provided in the Supporting Information S2. We assume that the total annual

284 water requirement for dust management is equivalent to $72 \mathrm{~mm}$ ( $2 \mathrm{~mm}$ per event) of precipitation.

285 Water use for the construction of PV infrastructure is also included in the life cycle analysis (see

286 Supporting Information S2).

287

\subsection{Integrated solar energy-aloe vera systems}

289 Based on the life cycle analysis of a stand-alone solar PV system and aloe vera cultivation, we

290 investigated the potential to integrate these two emerging land uses in northwestern India to

291 identify the synergies and tradeoffs of colocation. We also conducted detailed economic analyses

292 of colocated systems and the potential of these systems to improve rural livelihoods in

293 northwestern India.

\section{$294 \quad 2.4$ Sensitivity and uncertainty analyses}

295 Sensitivity analysis (one-at-a-time local sensitivity analysis) was performed for solar PV

296 installation and aloe vera cultivation. We defined a base case of the parameters considered,

297 identified a range of uncertainty for each parameter, and then tested the effect of changing each

298 parameter (on energy input/output and GHG emissions/offsets) from its minimum to maximum

299 value. We used the module efficiency, irradiation, performance ratio and number of modules $\mathrm{ha}^{-1}$ 
300 for the solar PV infrastructure and overall leaf to gel conversion rate and number of plants ha ${ }^{-1}$

301 for the aloe vera gel system as input parameters (see Supporting Information S3).

303 We addressed the uncertainty in our analysis by using a Monte Carlo simulation approach. The 304 analysis was performed using the input values of the most sensitive input parameters for solar 305 PV and aloe vera gel, identified by sensitivity analysis. The input parameters considered for solar 306 installation were efficiency (range of 14 to $16 \%$ ) and number of modules ha $^{-1}(3,000$ to 3,500$)$.

307 The input variables considered for aloe vera gel were the overall leaf to gel conversion rate (25 308 to $35 \%)$ and number of plants $\mathrm{ha}^{-1}(20,000$ to 25,000$)$. The input variables were assumed to be 309 independent and were randomly selected from a uniform distribution. The output simulation was 310 repeated $10^{4}$ times. The maximum, mean, minimum, and quantiles of outputs for solar PV 311 (outputs: energy input, energy output, GHG emissions, and net greenhouse gas offsets) and the 312 two yield scenarios of aloe (outputs: energy input, GHG emissions) were reported (see 313 Supporting Information S3).

\section{$315 \quad 2.5$ Economic analysis}

316 An economic analysis was conducted to compare landowner returns on single land use to

317 combined land use, both for grid-tied and off-grid cases. The analysis considered five project

318 designs or land use scenarios, each evaluating the economic return to a five-hectare plot in

319 Rajasthan. The land use scenarios considered are Aloe only, Off-grid PV only, Grid-tied PV

320 only, Off-grid Combined and Grid-tied combined. This economic analysis assumes the

321 landowner is an individual, rather than a business, and thus is ineligible to capture cash benefits

322 from tax-related incentives such as accelerated depreciation. Furthermore, the analysis assumes 
323 that the PV system is used for a variety of uses, not solely for agriculture; thus, subsidies for

324 irrigation-related electricity demand are not considered.

\subsubsection{Agriculture-related Assumptions}

327 Each model scenario that involved aloe cultivation (scenarios A, D, and E) uses the same input 328 assumptions. Each hectare can support 22,500 aloe plants, with each plant capable of producing

$3292 \mathrm{~kg}$ of finished product (aloe gel) per year (resulting in 50,000 kg of processed aloe ha ${ }^{-1} \mathrm{year}^{-1}$ ).

330 At a market price of 150 Indian Rupees (INR) per kilogram for aloe gel, this results in revenues

331 of INR 7.5 $\mathrm{M} \mathrm{ha}^{-1}$ year $^{-1}$. Planting costs are INR 75,000 per hectare, while annual crop

332 maintenance costs are INR 37,000 per hectare. The aloe plants can be harvested 3.5 times per

333 year beginning in year two. Planting costs occur in year one of the plant's life while crop

334 maintenance costs and revenues occur in years two through five. Immediately after the five-year

335 cycle, new plants are grown, and this plant cycle is repeated during the 30 -year evaluation

336 period. The model assumes that all five hectares are cultivated on the same schedule, rather than

337 rotating between hectares to smooth cash flow. Initial capital costs of INR $2 \mathrm{M}$ and INR $1 \mathrm{M}$ are 338 incurred for machinery and buildings, respectively; annual operation and maintenance costs are 339 of INR 600,000. The annual cash flow profile associated with aloe production (in scenarios A, D, 340 and E) is shown in the Supporting Information S4.

\section{$341 \quad$ 2.5.2 Solar PV Assumptions}

342 The solar PV analyses assume a default power density of $400 \mathrm{~kW} / \mathrm{hectare}$, totaling $2 \mathrm{MW}$ for the 343 five-hectare plot. Two different scenarios were considered for the solar PV analysis: a grid-tied 344 and off-grid system. The off-grid systems assumed that the PV system would offset diesel 
consumption (valued at INR 14.7 per kWh / U.S. dollar $\$ 0.25$ per $\mathrm{kWh}$ ) for three types of consumers: site-based agricultural electricity consumption, residential consumption, and nonresidential (or commercial) consumption. Therefore, the consumption of each of these consumer classes is valued at what they would have paid to consume diesel-based electricity.

For grid-tied cases, the analysis used prevailing retail electricity rates and solar feed-in tariff (FiT) for Rajasthan (Supporting Information). The grid-tied cases assume that the landowner would build a PV system of the same capacity as above ( $400 \mathrm{~kW} \mathrm{ha}^{-1}$ or $2 \mathrm{MW}$ total) and sell all electricity generated to the local grid. This implies that residential and commercial consumers would purchase directly from the grid and are therefore not reflected in the grid-tied cases. The landowner would receive FiT payments for all kilowatt-hours sold to the grid and purchases electricity for agricultural production at the agricultural rate for electricity. In this analysis we did not account for the cost subsidies provided by governmental agencies for installing large solar infrastructures in this region.

The system design specifications were developed using HOMER, a cost optimization tool. The HOMER model optimized a system design that kept PV capacity constant across scenarios in order to provide a meaningful comparison. Cash flow profiles for the off-grid and grid-tied cases are shown in Supporting Information S4. The resulting output combines capital costs (of PV technologies, batteries, inverters, and a diesel generator to provide consistent production), total production costs, and annualized values for replacement costs and operations and maintenance (which explains why the cash flow profiles below appear to be smooth). 


\section{3. Results and discussion}

368 The total energy inputs for solar PV infrastructure (412 GJ ha ${ }^{-1}$ year ${ }^{-1}$ and gross GHG emissions

369 of $39.6 \mathrm{Mg} \mathrm{CO}_{2} \mathrm{e} \mathrm{ha}^{-1}$ year $^{-1}$ ) are several times higher than the aloe vera baseline yield (28.14 GJ

$370 \mathrm{ha}^{-1}$ year $^{-1}$ and $2.01 \mathrm{Mg} \mathrm{CO}_{2} \mathrm{e} \mathrm{ha}^{-1}$ year $^{-1}$ ) and high yield (52.59 $\mathrm{GJ}^{-1}$ year $^{-1}$ and $4.06 \mathrm{Mg} \mathrm{CO}_{2} \mathrm{e}$

$371 \mathrm{ha}^{-1}$ year $^{-1}$ ) scenarios of aloe vera cultivation (Figures 2 and 3, Table 1). However, the solar PV

372 has an average energy output of $2590 \mathrm{GJ} \mathrm{ha}^{-1}$ year $^{-1}$ and gross GHG offset of $736 \mathrm{Mg} \mathrm{CO}_{2} \mathrm{e} \mathrm{ha}^{-1}$

373 year ${ }^{-1}$. The energy ratio (energy output to input) was around 6:1 for solar PV installation (Table

374 1). The energy ratios are consistent with existing life cycle studies of large solar installations in

375 desert regions. The water requirements for cleaning solar PV installation were higher than the

376 water requirements for baseline and high yield scenarios of aloe vera. 


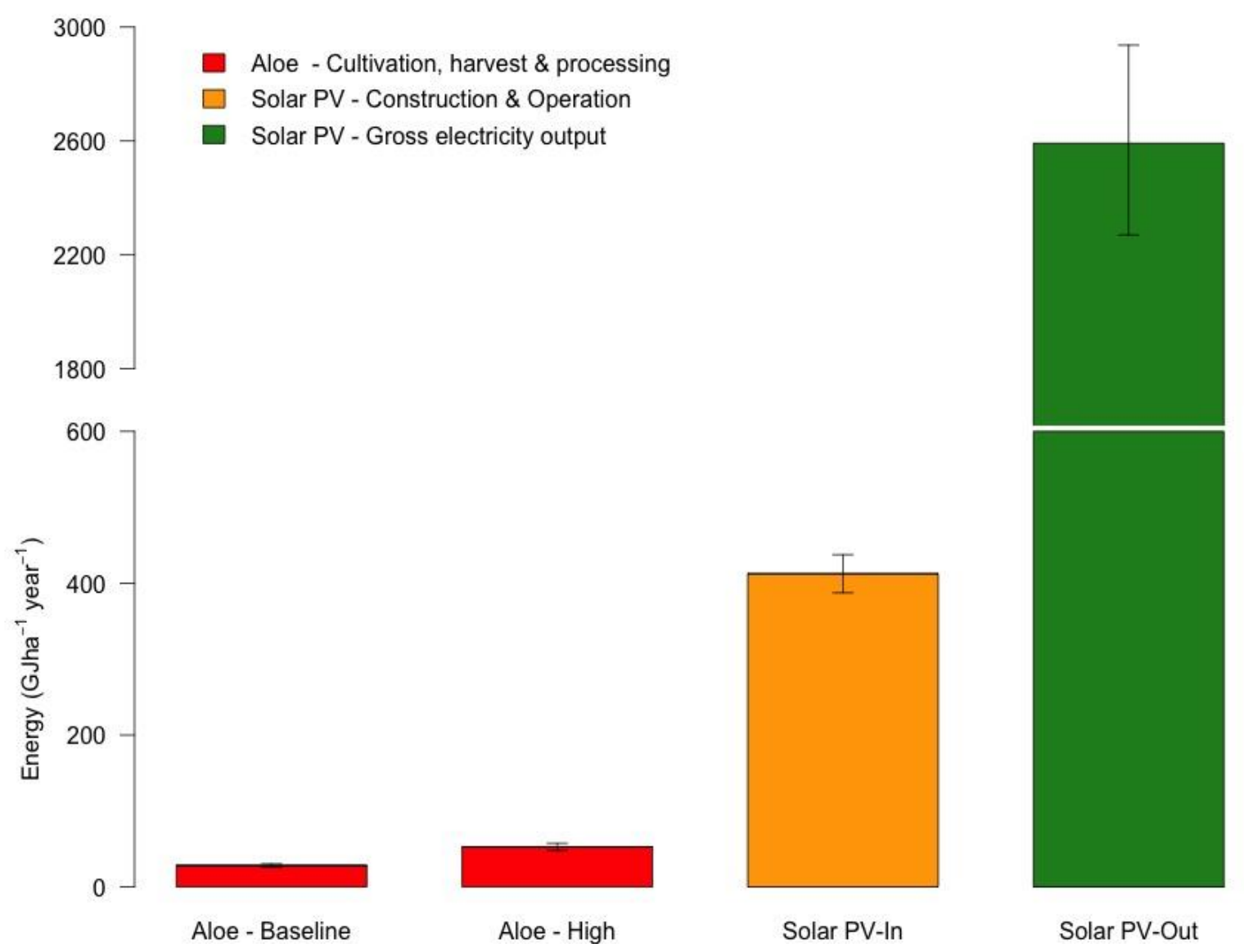

379 Figure 2 Life cycle energy inputs and outputs of solar PV and Aloe vera cultivation. The error

380 bars represent the uncertainty in our analysis as determined by Monte Carlo analysis in which the 381 most important parameters, as determined by sensitivity analysis, were varied. 

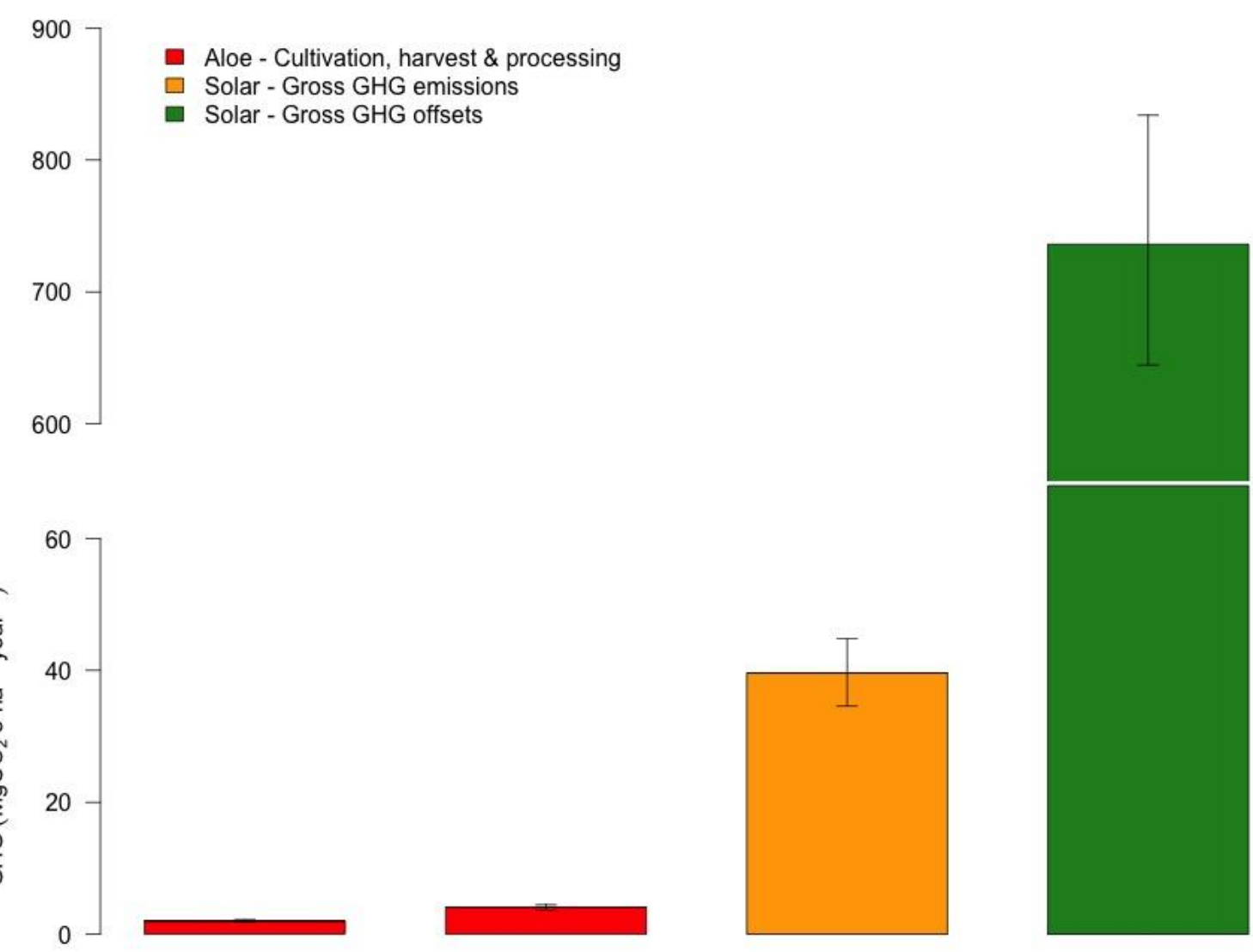

Aloe - Baseline

Aloe - High

Solar PV-Emissions

Solar PV-Offsets

384 Figure 3 Life cycle GHG emissions of aloe vera cultivation and gross GHG emissions and

385 offsets of solar PV. The error bars represent the uncertainty in our analysis as determined by

386 Monte Carlo analysis in which the most important parameters, as determined by sensitivity

387 analysis, were varied. 
394 Table 1. Summary of annual life cycle energy and GHG from Solar PV and aloe vera gel (5\% $395-95 \%$ quantile values are in brackets)

\begin{tabular}{|c|c|c|c|c|}
\hline Land use & $\begin{array}{l}\text { Gross } \\
\text { Energy } \\
\text { output } \\
\left(\text { GJha }^{1} \mathrm{y}^{-1}\right)\end{array}$ & $\begin{array}{l}\text { Gross GHG } \\
\text { offsets } \\
\left(\mathrm{MgCO}_{2} \mathrm{eha}^{-1} \mathrm{y}^{-1}\right)\end{array}$ & $\begin{array}{l}\text { Energy input } \\
\left(G J h^{-1} y^{-1}\right)\end{array}$ & $\begin{array}{l}\text { GHG emissions } \\
\left(\mathrm{Mg} \mathrm{CO}_{2} \mathrm{e} \mathrm{ha}^{-1} \mathrm{y}^{-1}\right)\end{array}$ \\
\hline Solar PV & $\begin{array}{l}2592 \\
(2365 \\
2828)\end{array}$ & $\begin{array}{l}735 \\
(671.8-803.1)\end{array}$ & $\begin{array}{l}413 \\
(389.6-435)\end{array}$ & $\begin{array}{l}39.6 \\
(35.7-43.2)\end{array}$ \\
\hline $\begin{array}{l}\text { Aloe - } \\
\text { High yield }\end{array}$ & - & - & $\begin{array}{l}52.6 \\
(48.3-56.9)\end{array}$ & $\begin{array}{l}4.1 \\
(3.7-4.4)\end{array}$ \\
\hline $\begin{array}{l}\text { Aloe- } \\
\text { baseline } \\
\text { yield }\end{array}$ & - & - & $\begin{array}{l}28.1 \\
(26.1-30.3)\end{array}$ & $\begin{array}{l}2.01 \\
(1.8-2.2)\end{array}$ \\
\hline
\end{tabular}

398

399 Results of the economic analysis indicate that in grid-tied cases, the landowner would receive 400 more benefits by simultaneously pursuing both productive uses of the land. Economic benefits 401 are additive when combining land uses because there is no reduction in PV capacity by 402 cultivating aloe in the same area, due to panel spacing restrictions of PV installations. Combining 
403 projects with positive net present value (NPV) leads to greater combined NPV. In this case, the 404 grid-tied PV scenario has a positive NPV, so combining this land use with aloe cultivation yields 405 a higher total project benefit. Off-grid (or microgrid) PV projects tend to have much higher 406 capital costs, which occur early in the project's life and heavily impact the discounting of project 407 benefits. This is the primary reason for the significantly negative NPV for the off-grid scenarios. 408 Capital costs for off-grid PV are INR $351 \mathrm{M}$ compared to INR $191 \mathrm{M}$ for a grid-tied system of 409 this type. Combining aloe cultivation with off-grid PV improves the landowner's NPV, but is 410 still negative in terms of revenues. The NPV of each scenario is shown in Figure 4 (calculated at 411 a 10\% discount rate throughout the analysis).

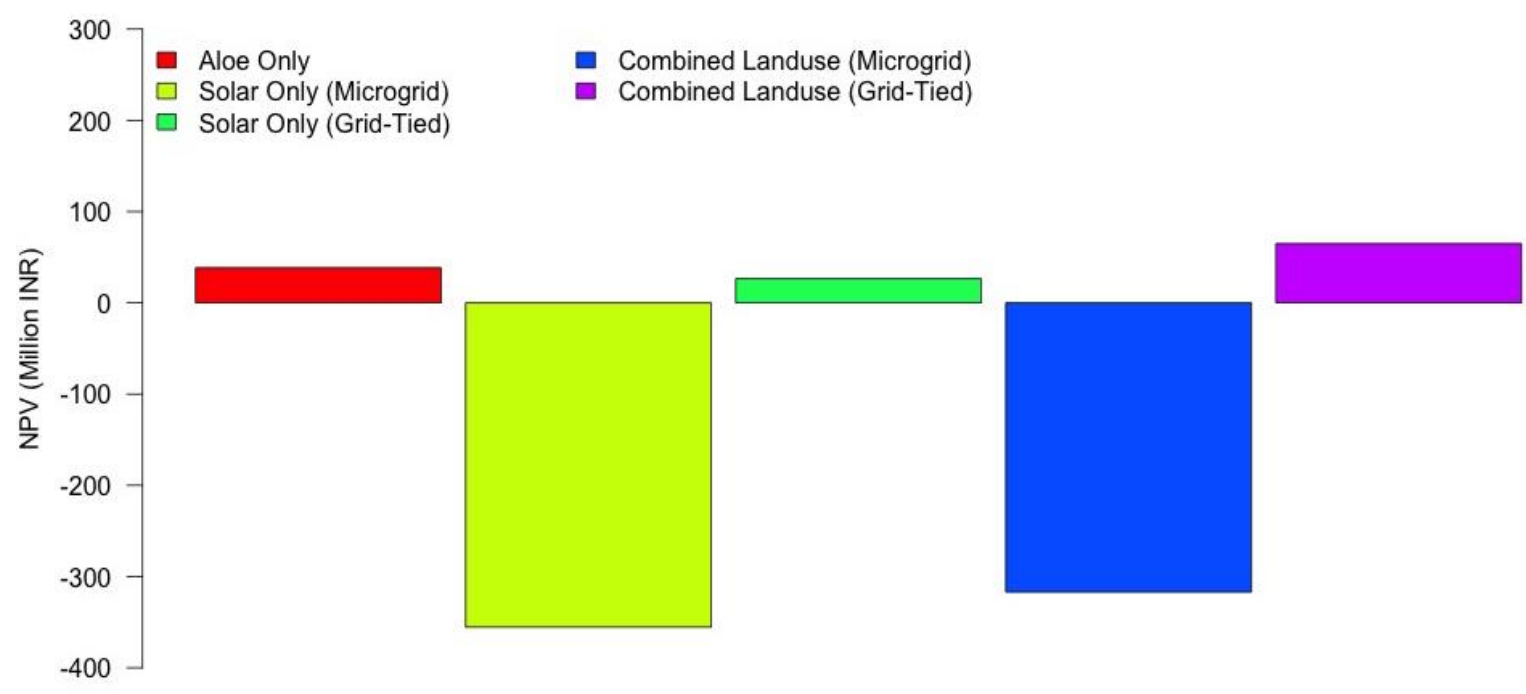

414 Figure 4 Net Present Value of five land use scenarios (10\% discount rate over 30 years). 
416 Figure 5 shows the landowner's cash flows profiles for each of the five cases. It is important to

417 note that the only negative cash flows periods occur during construction of the PV plant.

418 Similarly, in the aloe-only case, cash flow is negative each year there is a replanting. In the

419 combined land use scenarios, the cash flow is never negative after construction suggesting that

420 this scheme may also provide more resilient aggregate cash flow to the landowner.

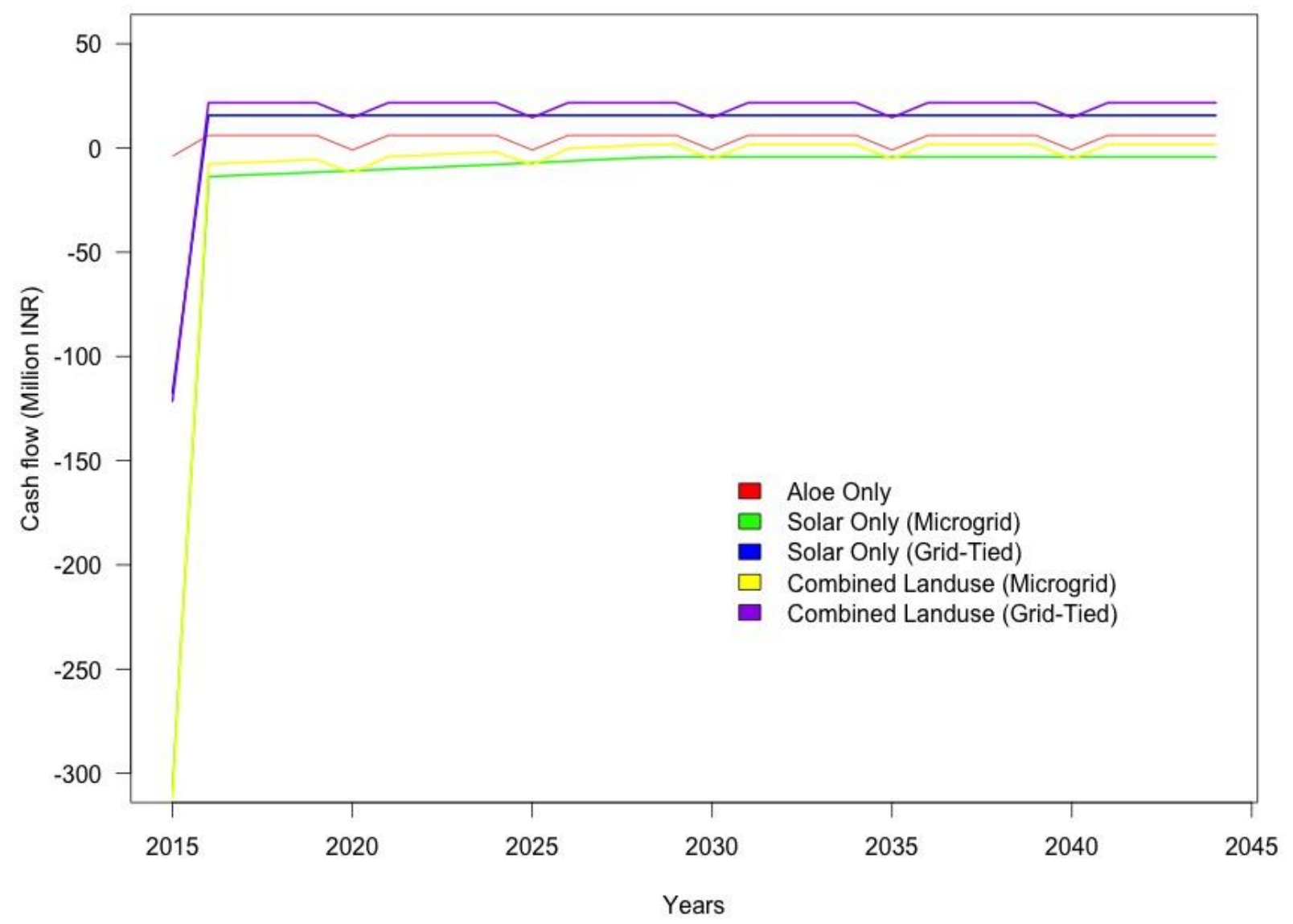

421

422 Figure 5 Cash flows of five land use scenarios 
424 Aloe cultivation is a highly productive use of the land, while the solar scenarios are less so on an

425 NPV basis. As mentioned above, the grid-tied PV case delivers a positive NPV, while the off-

426 grid case is negative. This is largely because capital costs in year one are much larger for the off-

427 grid cases due to the additional expense of batteries for the PV system. An impact that

428 counteracts this effect is that off-grid kilowatt-hours are valued at INR 14.7 per $\mathrm{kWh}$ while grid-

429 tied kilowatt-hours are valued at the FiT of INR 8.75 per kWh. However, timing effects from

430 discounting have a greater impact on the resulting NPV. In both cases, though, including aloe as

431 a productive land use improves the NPV to the land owner, increasing the grid-tied PV plant

432 from INR $40 \mathrm{M}$ to INR $66 \mathrm{M}$, and the off-grid plant from INR -355 M to INR -315 M, as seen in

$433 \quad$ Figure 4.

434 Sensitivity analysis indicated that the changes in the input parameters - efficiency and number

435 of modules for solar PV and overall sugar utilization efficiency and number of plants for aloe-

436 have significant impacts on the total energy input, gel production, and GHG offsets.

437 The Monte Carlo approach indicated aloe fresh leaf yield (annual) ranges from $24-30 \mathrm{Mg} \mathrm{ha}^{-1}$ for

438 the baseline scenario and $48-60 \mathrm{Mg} \mathrm{ha}^{-1}$ for the high yield scenario. The maximum and

439 minimum values for outputs are reported as error bars in figures 2 and 3 (see Supporting

440 Information S3).

441 The results presented above consider reference case input values. In order to incorporate

442 uncertainty and evaluate sensitivity to individual model inputs, a 10,000 trial Monte Carlo

443 simulation was conducted. NPVs for each of the five cases were defined as outputs for sensitivity

444 analysis, and Figure 6 below shows the range of results of each given $+/-20 \%$ ranges for selected

445 inputs. Uncertainty ranges were defined where information was available for specific inputs. The

446 frequency distributions below provide a glimpse of how certain the NPV results are. For 
447 example, the off-grid grid scenarios consistently show negative NPV values, whereas the grid-

448 tied PV-only scenario could show negative or positive NPV values, depending on inputs.

449 In addition to showing the range of possible outputs, the Monte Carlo analysis can reveal how

450 sensitive an output is to a given input. This is typically displayed with a tornado chart, which

451 shows the most sensitive inputs for each of the scenario NPV results (see Supporting Information

452 S4). These tornado charts provide a meaningful comparison of the input sensitivities because all

453 uncertainty ranges are identical. In general, prices and consumption are the most sensitive

454 variables for both PV and aloe scenarios. Capital costs were excluded from the sensitivity

455 analysis because they were modeled outside of the economic model in HOMER, so the

456 relationships between capital costs and capacity and production would not hold in this economic

457 model if included in the sensitivity analysis. If included in the sensitivity analysis, capital costs

458 would be much more sensitive, both because they are significant relative to other cash flows and 459 because they occur in year one. 


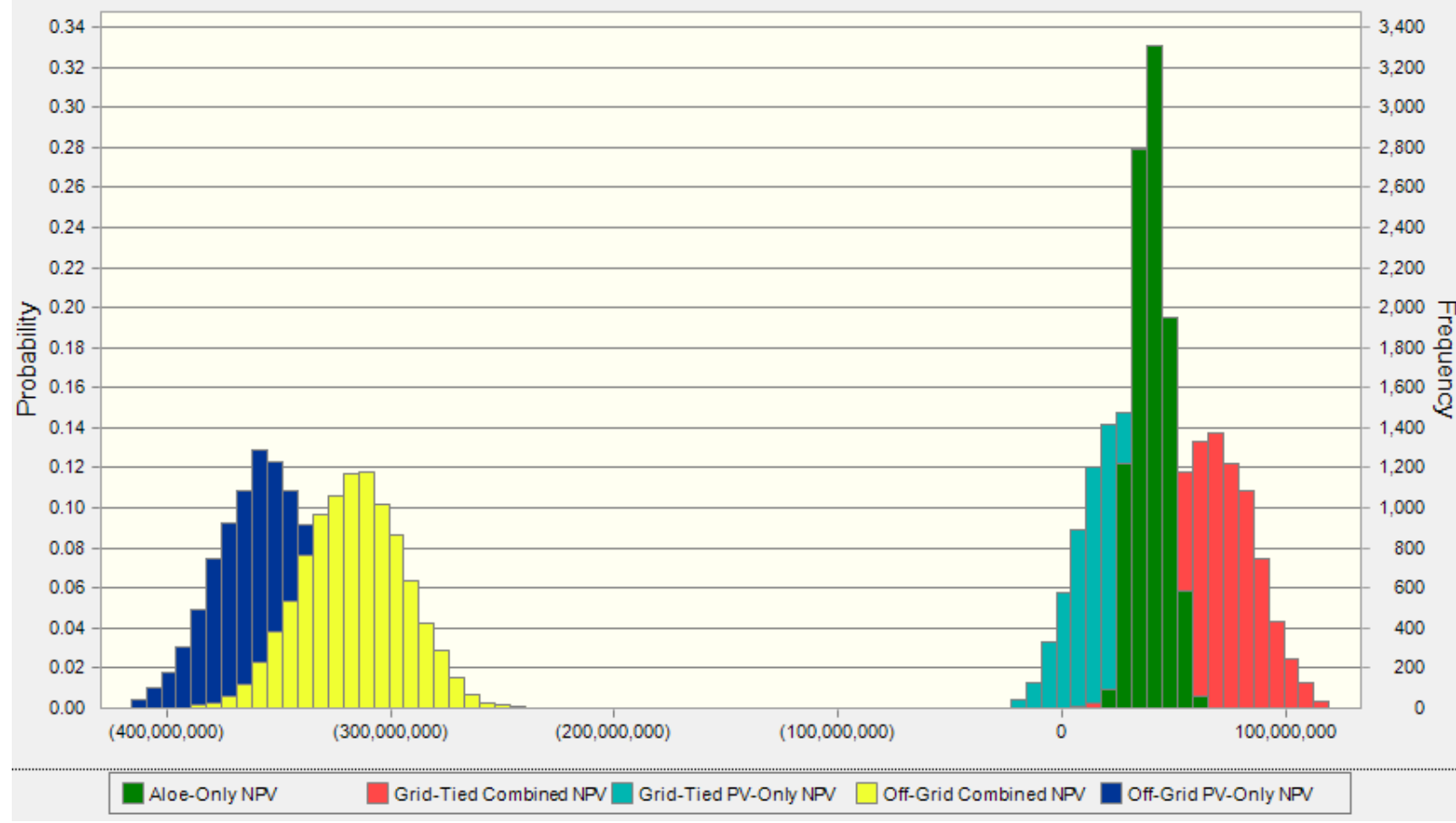

462 Figure 6 NPV frequency distributions from Monte Carlo analysis (10,000 trials) where the x463 axis represents NPV in INR.

In addition to the Monte Carlo analysis, an evaluation was conducted to examine the impact of a $46610 \%$ reduction in PV capacity that could result from combining land use. For this assessment,

467 only the PV capacities in the two combined land use scenarios were reduced by $10 \%$ from 400

$468 \mathrm{~kW} \mathrm{ha}^{-1}$ to $360 \mathrm{~kW} \mathrm{ha}^{-1}$. Interestingly, the NPV decreases in the microgrid case, but marginally

469 increases in the grid-tied combined land use case. This is primarily due to system design. In

470 order for a microgrid to support a certain load at lower PV capacity, battery capacity should be

471 increased, thereby offsetting some of the cost reduction from capacity decreases. In a lower load

472 case $\left(1,500 \mathrm{kWh}\right.$ day $^{-1}$ versus $1,700 \mathrm{kWh}$ day $\left.^{-1}\right)$, the NPV of the microgrid case increases to INR 
$47356 \mathrm{M}$. This implies that the microgrid scenario is very sensitive to system design and therefore 474 cost.

475 In our analysis of colocation, the synergy between solar PV system and aloe vera cultivation

476 stems from the fact that the water inputs for cleaning solar panels are similar to amounts required

477 for annual aloe production, suggesting the possibility of integrating the two systems on the same 478 plot of land to maximize land and water use efficiency. The life cycle analyses show that the 479 colocated systems are economically viable in some cases and may provide opportunities for rural 480 electrification and stimulate economic growth. A life cycle analysis of a hypothetical colocation 481 system in northwestern India indicated higher economic returns per $\mathrm{m}^{3}$ of water used than either 482 system alone, an important consideration in an arid area. We considered the output from the 483 uncertainty analysis of the average aloe yield scenario and average solar PV to estimate the 484 economics range of different land use scenarios (See supporting information S4). When water 485 productivity is expressed in terms of net benefits $\left(\mathrm{INR} \mathrm{m}^{-3}\right.$ ) the aloe vera cultivation (low yield 486 scenario for leaf production only at INR $2 \mathrm{~kg}^{-1}$ ) $[43,44]$ resulted in much higher returns $\mathrm{m}^{-3}$ of 487 water used INR 60 (baseline yield scenario) compared to agricultural crops in the region (INR 2488 12) [56]. The results from our economic analysis indicate that the processing of aloe to gel leads 489 to a substantial increase (over 10 times) in water productivity compared to the aloe leaf 490 production only scenario. The water productivity of solar PV installation (grid-tied) by far 491 exceeds other land uses (over 250 - 1500 times normal agricultural crops in the region) and when 492 colocated with aloe cultivation (for gel production) the water productivity and economic benefits 493 are much higher (30\% higher), highlighting the synergies of colocation. In the case of micro 494 grids, the colocation leads to an even higher increase in returns ( $40 \%$ higher), indicating that 495 colocation may have the potential to make some offgrid systems profitable. The benefits will be 
496 substantially higher if we account for subsidies provided by governmental organizations for

497 installing large solar installations, particularly in the case of micro grids.

498 Colocated systems may provide several co-benefits. In rural areas not connected to the electricity

499 grid, colocation of aloe cultivation with standalone solar infrastructures has the potential to

500 stimulate economic growth by aiding in rural electrification and creating stable employment

501 opportunities for agricultural laborers (e.g., in cultivation and processing of aloe or other local

502 agricultural commodities). Studies have indicated that electricity availability is a significant

503 driver of development in rural areas by stimulating economies, providing job security, and

504 improving health and education [57,58]. The labor requirements for large solar infrastructures are

505 mostly concentrated during the construction phase. The colocation of agriculture with solar

506 facilities may provide continuous employment opportunities for routine agricultural operations

507 (farm labor and processing).

508 Colocation of solar PV and agriculture in rural areas may provide several new and feasible

509 technologies for solar energy applications in the agricultural sector $[59,60]$. Common

510 applications of solar energy in agriculture include solar irrigation systems, photovoltaic heating

511 and refrigeration systems, solar - based processing units for agriculture commodities, and solar

512 greenhouses $[59,60]$. In rural areas not connected to the grid, solar water pumps provide an

513 environment friendly alternative to diesel pumps with high emissions [59, 61]. Solar- powered

514 desalination systems can be used to provide irrigation water in some arid regions with limited

515 access to fresh water resources [62]. Further, rural electrification provides rural farming

516 communities easy access to up-to-date agriculture-related information and weather forecasts,

517 thereby enabling faster adoption of improved crop and water management practices. Overall,

518 colocation may contribute to sustainable agriculture and rural development $[59,61]$. 
519 Colocating crops in solar facilities may help to control soil erosion by wind and water by

520 maintaining an effective ground cover (aloe), improving soil moisture in surface soil and

521 potentially reducing dust emissions from disturbed soils and improving air quality in the region

522 [25]. Moreover, solar panels may result in enhanced moisture availability to aloe plants by

523 channeling or concentrating rainfall on to the interspaces, thereby amplifying the background

524 precipitation for plants. Partial shading by solar panels may provide benefits to aloe plants grown 525 in desert conditions with high available solar radiation [39]. Further, CAM plants like aloe vera

526 are known to benefit from increase in atmospheric $\mathrm{CO}_{2}$ and are tolerant to droughts and high

527 temperatures, which are expected to be more frequent in the future [38].

528 Colocation may not be practical in all locations, and further field studies are required to fully 529 evaluate the advantages and disadvantages of colocation [62]. We acknowledge that before field 530 level implementation of large colocated systems, long-term field experiments are needed to fully 531 understand the benefits and synergies of colocation in different regions. For example,

532 considerable uncertainties remain on aloe yield under colocated conditions and the impact of 533 periodic water addition (from washing panels) and partial shading on aloe vera leaf yield and gel 534 quality. Reliable estimates of leaf yield and gel characteristics (quantity and quality) of various 535 aloe cultivars are critical for establishing the long-term economic and logistic viability of 536 commercial aloe vera gel production. Another factor that needs consideration is determining the 537 optimum packing density for solar modules and the optimal planting density for aloe vera. The 538 spacing of solar modules is an important factor because it impacts the space requirements for 539 plants and routine agricultural operations. Even though colocation might be possible in some of 540 the existing solar PV installations, design modifications (and additional costs) might be needed 541 to fully accommodate the colocation of aloe vera. The success of these systems depends on the 
542 timely availability of planting materials, gel processing machinery, and the ability to provide

543 technical guidance to local farmers. The life cycle assessment and ecological benefits depend

544 also on the electricity source used for cultivation practices such as irrigation. For example, in

545 scenarios where the farmers sell PV-sourced electricity to the local grid and buy electricity at the

546 agricultural rate, the environmental benefits depend on the source of the electricity used for

547 cultivation practices.

\section{4. Conclusions}

550 Colocated solar and aloe vera infrastructure could: (1) ensure efficient land and water use (both 551 PV cleaning water and precipitation) by sustaining agricultural production in marginal lands and

552 maximizing power output from solar PV; (2) increase area of high value crops and thereby

553 minimize the socioeconomic and environmental issues resulting from cultivation of high value

554 non-food crops (e.g., aloe) in prime agricultural lands; (3) stimulate rural economies by creating

555 employment and providing opportunities for rural electrification; and (4) improve regional air 556 quality by reducing soil erosion and dust emissions from large solar infrastructures. The water

557 requirement for aloe vera cultivation is low compared to other agricultural crops, and aloes can

558 survive and produce significant biomass in nutrient poor soils and in adverse climatic conditions.

559 In northwestern India, solar deployment is increasing rapidly, with growing concerns on the fate

560 of land and water resources in this region. This study indicates that there is potential to integrate

561 high value crops with these large solar installations with no additional land or water use.

562 Based on an optimistic scenario of solar expansion in India, there is potential to install $100 \mathrm{GW}$

563 in the next decade [63]. This expansion will translate into over 250000 ha of direct land 
564 transformation, mostly in the arid regions of northwestern India. Assuming that all these areas

565 could be integrated with aloe vera cultivation, over $7-14$ million tons year ${ }^{-1}$ (base and high

566 yield scenarios respectively) of aloe vera leaves could be produced, with no additional water use

567 or land transformation. Colocation of high-value crops may make the off-grid solar PV systems

568 economically viable in certain configurations, thereby providing co-benefits including rural

569 electrification, reduced diesel consumption (and associated reductions in GHG emissions), and

570 employment generation. The northwestern state of India (Rajasthan), identified as the one of the

571 hotspots for solar energy development in India, has a population of over 70 million with access

572 to only $1 \%$ of India's water resources. The region has experienced high population growth $(10 \%)$

573 in the past decade (2001-2011), creating additional demand for land and water resources. In

574 these water-limited areas, colocated solar infrastructure and aloe cultivation could be established

575 in marginal lands with low water use, thus minimizing the socioeconomic and environmental

576 issues resulting from cultivation of non-food crops (e.g., aloe) in prime agricultural lands.

577 Acknowledgements:

578 The Joint Institute of Strategic Energy Analysis (JISEA - IRAAP), TomKat Center for

579 Sustainable Energy at Stanford University, Council on Environment, Energy \& Water (CEEW).

580

\section{References}

581 [1] GEA. Global Energy Assessment - Toward a Sustainable Future. Cambridge University

[2] U.S. Department of Energy. SunShot Vision Study. 2012. Energy Efficiency and Press, Cambridge, UK and New York, NY, USA and the International Institute for Applied Systems Analysis, Laxenburg, Austria: 2012.

Renewable Energy, U.S. Department of Energy. NREL Report No. BK5200-47927; DOE/GO-102012-3037. 
[3] Garg P. Energy Scenario and Vision 2020 in India. J Sustain Energy Environ 2012;3:717.

[4] Schuman S, Lin A. China's Renewable Energy Law and its impact on renewable power in China: Progress, challenges and recommendations for improving implementation. Energy Policy 2012;51:89-109. doi:10.1016/j.enpol.2012.06.066.

[5] Tsoutsos T, Frantzeskaki N, Gekas V. Environmental impacts from the solar energy technologies. Energy Policy 2005;33:289-96. doi:10.1016/S0301-4215(03)00241-6.

[6] Brown P, Whitney G. U . S . Renewable Electricity Generation : Resources and Challenges. Congressional Research Service, 7-5700 R41954, Washington D.C. 2011.

[7] Hernandez RR, Easter SB, Murphy-Mariscal ML, Maestre FT, Tavassoli M, Allen EB, et al. Environmental impacts of utility-scale solar energy. Renew Sustain Energy Rev 2014;29:766-79. doi:10.1016/j.rser.2013.08.041.

[8] Ravi S, Lobell DB, Field CB. Tradeoffs and Synergies between biofuel production and large solar infrastructure in deserts. Environ Sci Technol 2014;48:3021-30. doi:10.1021/es404950n.

[9] Hernandez RR, Hoffacker MK, Field CB. Land-use efficiency of big solar. Environ Sci Technol 2014;48:1315-23. doi:10.1021/es4043726.

[10] Bazilian M, Rogner H, Howells M, Hermann S, Arent D, Gielen D, et al. Considering the energy, water and food nexus: Towards an integrated modelling approach. Energy Policy 2011;39:7896-906. doi:10.1016/j.enpol.2011.09.039.

[11] World Economic Forum. Water Security: The Water-Food-Energy-Climate Nexus. Washington D.C: Island Press; 2011.

[12] Xue Y, Xiao S. Generalized congestion of power systems: insights from the massive blackouts in India. J Mod Power Syst Clean Energy 2013;1:91-100. doi:10.1007/s40565013-0014-2.

[13] CEEW. Laying the Foundation for a Bright Future Assessing Progress Under Phase 1 of India's National Solar Mission. 2012. Council on Energy, Environment and Water, New Delhi, 2012.

[14] Kapoor K, Pandey KK, Jain AK, Nandan A. Evolution of solar energy in India: A review. Renew Sustain Energy Rev 2014;40:475-87. doi:10.1016/j.rser.2014.07.118.

[15] CEEW. Concentrated Solar Power : Heating Up India's Solar Thermal Market under the National Solar Mission. 2012. IP:12-010-A, Council on Energy, Environment and Water, New Delhi, 2012. 
620

621

622

623

624

625

626

627

628

629

630

631

632

633

634

635

636

637

638

639

640

641

642

643

644

645

646

647

648

649

650

651

[16] Ramachandra TV, Jain R, Krishnadas G. Hotspots of solar potential in India. Renew Sustain Energy Rev 2011;15:3178-86. doi:10.1016/j.rser.2011.04.007.

[17] Jodha NS. Population Growth and the Decline of Common Property Resources in Rajasthan, India. Popul Dev Rev 2014;11:247-64.

[18] Ravi S, Huxman TE. Land degradation in the Thar Desert. Front Ecol Environ 2009;7:517-8. doi:10.1890/09.WB.029.

[19] Amit D, Jethoo AS, Poonia MP. Impact of Drought on Urban Water Supply : A Case Study of Jaipur City. Int J Eng Innov Technol 2012;1:170-4.

[20] Burkhardt JJ, Heath GA, Turchi CS. Life cycle assessment of a parabolic trough concentrating solar power plant and the impacts of key design alternatives. Environ Sci Technol 2011;45:2457-64. doi:10.1021/es1033266.

[21] Kimber A, Mitchell L, Nogradi S, Wenger H. The effect of soiling on large gridconnected photovoltaic systems in California and the Southwest Region of the United States. Conf. Rec. 2006 IEEE 4th World Conf. Photovolt. Energy Conversion, WCPEC-4, vol. 2, 2007, p. 2391-5. doi:10.1109/WCPEC.2006.279690.

[22] Mani M, Pillai R. Impact of dust on solar photovoltaic (PV) performance: Research status, challenges and recommendations. Renew Sustain Energy Rev 2010;14:3124-31.

doi:10.1016/j.rser.2010.07.065.

[23] Weber B, Quiñones A, Almanza R, Duran MD. Performance Reduction of PV Systems by Dust Deposition. Energy Procedia 2014;57:99-108. doi:10.1016/j.egypro.2014.10.013.

[24] Field JP, Belnap J, Breshears DD, Neff JC, Okin GS, Whicker JJ, et al. The ecology of dust. Front Ecol Environ 2010;8:423-30. doi:10.1890/090050.

[25] Ravi S, D’Odorico P, Breshears DD, Field JP, Goudie AS, Huxman TE, et al. Aeolian Processes and the Biosphere. Rev Geophys 2011;49:RG3001. doi:10.1029/2010RG000328.

[26] Mohamed AO, Hasan A. Effect of Dust Accumulation on Performance of Photovoltaic Solar Modules in Sahara Environment. J Basic Appl Sci Res 2012; 2:11030-11036.

[27] Macknick J, Beatty B, Hill G. Overview of Opportunities for Colocation of Solar Energy Technologies and Vegetation, NREL/TO-6A20-60240, National Renewable Energy Laboratory, Golden, 2013.

[28] Davis SC, Dohleman FG, Long SP. The global potential for Agave as a biofuel feedstock. GCB Bioenergy 2011;3:68-78. doi:10.1111/j.1757-1707.2010.01077.x. 
[29] El Bassam N. C3 and C4 plant species as energy sources and their potential impact on environment and climate. Renew Energy 1998;15:205-10.

[30] Newton LE. Aloe. In: Urs E, editor. Illustrated Handbook of Succulent Plants, Berlin, Heidelberg and New York: Springer Verlag; 2001, p. 103-186.

[31] Reynolds T. Aloes: The genus Aloe. Boca Raton: CRC Press; 2004.

[32] Panda H. Aloe Vera Handbook Cultivation, Research Finding, Products, Formulations, Extraction \& Processing. Delhi: Asia Pacific Business Press Inc; 2003.

[33] Upton R, Axentiev P, Swisher D. Aloe vera Leaf Aloe vera Leaf Juice Aloe vera Inner Leaf Juics Aloe vera (L.) Burm. f. Standards of Identity, Analysis, and Quality Control. Scotts Valley: American Herbal Pharmacopoeia; 2012.

[34] Bassetti A, Saia S. The great aloe book. Trento: Zuccari Pty Ltd; 2005.

[35] Ahlawat KS, Khatkar BS. Processing, food applications and safety of aloe vera products: a review. J Food Sci Technol 2011;48:525-33. doi:10.1007/s13197-011-0229-z.

[36] Das N, Chattopadhay RN. Commercial cultivation of Aloe. Nat Prod Radiance 2004;3:857.

[37] Biswas B. Cultivation of Medicinal Plant Success Stories of Two Farmers. Fertil Mark News 2010; 41:1-4.

[38] Nobel PS. Environmental Biology of Agaves and Cacti. Cambridge: Cambridge University Press; 2003.

[39] Tawfik KM, Sheteawi SA, El-Gawad ZA. Growth and aloin production of Aloe vera and Aloe eru under different ecological conditions. Egypt J Biol 2004;3. doi:10.4314/ejb.v3i1.29929.

[40] Dagar JC, Tomar OS, Kumar Y, Bhagwan H, Yadav RK, Tyagi NK. Performance of some under-explored crops under saline irrigation in a semiarid climate in Northwest India. L Degrad Dev 2006;17:285-99. doi:10.1002/ldr.712.

[41] Chauhan SK. Effect of salinity levels, water regimes and nitrogen on crop growth and yield of Aloe. Ann Plant Soil Res 2013;15:58-61.

[42] Yan X, Tan DKY, Inderwildi OR, Smith JAC, King DA. Life cycle energy and greenhouse gas analysis for agave-derived bioethanol. Energy Environ Sci 2011;4:3110. doi:10.1039/c1ee01107c. 
[43] National Bank for Agriculture and Rural Development, http://farmextensionmanager.com/English/Agribusiness\%20oppertunities/Medicinal\%20p lant\%20sector/aloevera.htm, (accessed March 2015).

[44] Tamil Nadu Agricultural University, TNAU Agritech Portal, http://agritech.tnau.ac.in/farm_enterprises/Farm\%20enterprises_\%20aloevera.html, (accessed March 2015).

[45] Singh H, Mishra D, Nahar N. Energy use pattern in production agriculture of a typical village in arid zone, India - part I. Energy Convers Manag 2002;43:2275-86. doi:10.1016/S0196-8904(01)00161-3.

[46] Singh H, Mishra D, Nahar N., Ranjan M. Energy use pattern in production agriculture of a typical village in arid zone India: part II. Energy Convers Manag 2003;44:1053-67. doi:10.1016/S0196-8904(02)00115-2.

[47] Joshi B, Garg A, Sikarwar RLS, Tiwari AP. The Altered Output of Aloe vera (L.) Burm. f. Crop under Differential Water Stress Conditions. J Nat Remedies 2014;14:114-8.

[48] Rodríguez-García R, Rodríguez DJ de, Gil-Marín JA, Angulo-Sánchez JL, Lira-Saldivar RH. Growth, stomatal resistance, and transpiration of Aloe vera under different soil water potentials. Ind Crops Prod 2007;25:123-8. doi:10.1016/j.indcrop.2006.08.005.

[49] Silva H, Sagardia S, Seguel O, Torres C, Tapia C, Franck N, et al. Effect of water availability on growth and water use efficiency for biomass and gel production in Aloe Vera (Aloe barbadensis M.). Ind Crops Prod 2010;31:20-7. doi:10.1016/j.indcrop.2009.08.001.

[50] Ramachandra CT, Srinivasa Rao P. Processing of Aloe vera leaf gel: A review. Am J Agric Biol Sci 2008;3:502-10. doi:10.3844/ajabssp.2008.502.510.

[51] Pandey S, Singh VS, Gangwar NP, Vijayvergia MM, Prakash C, Pandey DN. Determinants of success for promoting solar energy in Rajasthan, India. Renew Sustain Energy Rev 2012;16:3593-8.

[52] Ito M, Kato K, Komoto K, Kichimi T, Kurokawa K. A comparative study on cost and lifecycle analysis for $100 \mathrm{MW}$ very large-scale PV (VLS-PV) systems in deserts using $\mathrm{m}-\mathrm{Si}$, a-Si, CdTe, and CIS modules. Prog Photovoltaics Res Appl 2008;16:17-30. doi:10.1002/pip.770.

[53] Fthenakis VM, Kim HC. Photovoltaics: Life-cycle analyses. Sol Energy 2011;85:160928. doi:10.1016/j.solener.2009.10.002.

[54] Raugei M, Bargigli S, Ulgiati S. Life cycle assessment and energy pay-back time of advanced photovoltaic modules: CdTe and CIS compared to poly-Si. Energy 2007; 32:1310-8. doi:10.1016/j.energy.2006.10.003. 
717 [55] Itten R, Frischknecht R, Stucki M. Life cycle inventories of electricity mixes and grid. Uster: Paul Scherrer Institute; 2014.

719 [56] Sharma P. Productivity based allocation of water for irrigation in Rajasthan. Mem Geol

[57] Mathur D, Mathur JK. Dark Homes and Smoky Hearths: Rural electrification and women. Soc India 2013;83:181-196.

[58] Barnes DF, Floor WM. Rural energy in developing countries: A Challenge for Economic Development. Annu Rev Energy Environ 2003;21: 497-530.

725

726

727

728

729

730

731

732

733

734

735

[63] CEEW, Tapping Every Ray of the Sun : A Roadmap for a significant role of solar in India, CEEW-Policy Brief, Council on Energy, Environment and Water, New Delhi, 2014.

[59] Mekhilef S, Faramarzi SZ, Saidur R, Salam Z. The application of solar technologies for sustainable development of agricultural sector. Renew Sustain Energy Rev 2013;18:58394. doi:10.1016/j.rser.2012.10.049.

[60] Chaibi MT. An overview of solar desalination for domestic and agriculture water needs in remote arid areas. Desalination 2000;127:119-33. doi:10.1016/S0011-9164(99)00197-6.

[61] Panwar NL, Kaushik SC, Kothari S. Role of renewable energy sources in environmental protection: A review. Renew Sustain Energy Rev 2011;15:1513-24. doi:10.1016/j.rser.2010.11.037.

[62] Ravi S. Resources: Partner crop plants with solar facilities. Nature 2015; 524:161. CEEW-Policy Brief, Council on Energy, Environment and Water, New Delhi, 2014. 
